\title{
The Prophetic Lens: A Missiological Function of Film for Black Social Movement from Martin Luther King, Jr. to the Camera Phone
}

\author{
Phillip Allen \\ Fuller Theological Seminary, Pasadena, CA, USA \\ philallen@fuller.edu
}

\begin{abstract}
Through technological advances and its democratization, the camera is found to have dual functionality. It is both a prophetic and a missiological tool used to awaken the collective conscience of a nation apathetic towards the Black experience and to offer a counter-narrative reorienting the US to becoming a more racially just society. This paper considers definitions of gospel, missions, and the prophetic, outlining a framework for how the camera functions in all three. It briefly explores the use of the camera from Martin Luther King, Jr., during the Civil Rights Movement, to the contemporary citizen with a camera phone, all capturing anti-Black violence. As we will see, like the parables of Jesus were to his kingdom message, the content of the camera has proven vital to acquiring justice by exposing the realities of racial injustice, confronting the status quo, and energising viewers to take positive action.
\end{abstract}

\section{Keywords}

camera - Martin Luther King, Jr. - George Floyd - missions - prophetic - gospel racism - beloved community

\section{Introduction}

After a brutal reception by police officers during a march in Selma, Alabama, in 1965, Martin Luther King, Jr. spoke the following words, to which Alexis Madrigal draws our attention: "We are here to say to the white men that we no longer will let them use clubs on us in the dark corners. We're going to make 
them do it in the glaring light of television." Significantly, "In that moment King was not just a pastor, rhetorician, and prophet, but a filmmaker" (Madrigal 2018). He did not stage the drama, but he strategically positioned himself and the demonstrators to allow the camera to capture events as they were ready to unfold.

King troubled the consciences of Americans with the intention of awakening them to the truth that Black peoples' once-camouflaged realities in the South warranted more than simple awareness, but intervention. King's task was to cast light on the depths of the destructive ways of racial injustice, presided over by Whites - even gospel-preaching White clergy; a way of existence for African Americans that included domestic terror lynchings, police brutality, and daily dehumanizing encounters with their White counterparts. What King understood, along with journalists and ordinary camera-phone-using citizens today, is that images impact us in ways that words do not. For the collective conscience of the White/non-Black community (under the spell of white supremacy) to be moved to action, it required, and continues to require, more than dissemination of information or even passionate rhetoric, but visual imagery capturing the violence of anti-Black racism in action. This paper contends that seeing the use of the camera ${ }^{1}$ - with its corresponding visual content - as an instrument for prophetic, missiological purposes can firstly give agency to the Black community, who have traditionally been neutralized economically, physically, and psychologically; and secondly, present an alternative, liberative narrative that exposes anti-Black violence and catalyzes the masses towards the missiological work of justice, which is inherent to the gospel message.

In this paper I present the video camera as a cultural artifact used in contemporary resistance movements against social injustice in the US. In doing this, I use a historical approach tracing the significance of the video camera from the Civil Rights Movement of the 1950's-'6os to the recording of George Floyd's murder in 2020. I hold in conversation liberative, justice-focused theologians with conservative, evangelical theologians to formulate definitions for "gospel" and "missions." Walter Brueggemann's work on the prophetic ministry in The Prophetic Imagination (2001) is employed as a framework for understanding the implications of the camera functioning as a prophetic witness (i.e., revealing the depth of injustice and providing the rationale and urgency for the gospel), but also as a missiological witness in the missio Dei. Further, I use King's "beloved community" idea as the telos for an intrinsically justice-oriented

1 Within this paper, I use the term 'camera' broadly to include all visual filming devices, whether producing still or live images. However, I am primarily focused here on camera phones, which have become the most ubiquitous 'video camera' available. 
missio Dei, while Brueggemann's counter-community concept - a community of solidarity - is captured by the beloved community.

\section{$2 \quad$ Problematizing the Camera}

A few words must be said here before moving on. Certainly, film and photographs have been used to widely differing ends, both positive and negative. The term "poverty porn" is sometimes used to describe the ways in which journalists, missionaries, or charities (for example) share sensationalised images of deeply impoverished communities with wealthier audiences, hoping to profit from print or news media, or to raise donations from sympathetic, or guilty, donors. At the same time, sometimes this is simply the honest recording of very difficult circumstances, of which it is important for the world to be aware.

Likewise, there can be tension between those who have used/misused images of foreign communities alternately in exploitive ways, as the 'exotic other,' or simply a straightforward informational ways, recording different people/communities in various parts of the world. Missionaries, for example, have fallen into both camps at different times. Again, taking note of these differing motivations is important: it is not all exploitative nor all innocent, but should be carefully considered.

There is also a lot that can be said about the power dynamics of the person "capturing" the images, and those "being captured." Sometimes it is clear that the power balance is tipped entirely to the person behind the lens; but at other times, they and the camera appear to function more as servants to those being recorded, standing as silent witnesses to the events at hand.

These issues, while important to bear in mind, are not our focus here. However, with so many different approaches and contested categories relating to the use of cameras/film, particularly within missions history, it is significant to be aware of these tensions. With this in mind, my focus here is on one positive use of film in a specific context - racial justice movements in the US - in order to posit a prophetic function of the camera/film with significant missiological relevance for global justice-seeking efforts.

\section{3 "Framing" the Gospel and Missions}

\subsection{The Gospel}

The gospel is fundamentally a narrative or drama about the person of Jesus - his birth, ministry, suffering, death, and resurrection for the salvation of humanity. 
However, the gospel is more than just good news of personal salvation. It must necessarily be understood as a liberative, justice-oriented message: "Matthew, Mark, Luke, and John all cared about an individual's reconciliation with God, self, and their communities. But the gospel writers also focused on systemic justice ... and freedom for the oppressed" (Harper 2016:6). As justice is intrinsic to the character of God, the church must make room for its embeddedness in the gospel message, and thus the missio Dei. "The gospel is without constrictors of space. It is quintessentially movable, elastically stable over vastly different locations" (Jennings 2010:31; emphasis mine).

Vince Bantu continues the throughline of an expanded understanding of the gospel, as he succinctly defines it here: "The Gospel means liberation from all forms of oppression and sin through faith in Christ. The Gospel signals freedom through Christ in all areas of life. When the God of Israel sent his servant Moses to declare His message of liberation to Pharaoh, the imperative was followed with a statement of intent: God's desire was freedom for His people so that they might worship Him. The foundation of liberation from social oppression is found in the Word of God; the telos of social liberation is the worship of God alone" (Bantu 2020:9).

This gospel narrative of the coming kingdom engages the culture in the kingdom's character in two ways: it invites and it confronts. This gospel first invites humanity into a story of solidarity (died for our sins), prophetic witness (in accordance with the Scriptures), and redemption (Jesus was raised on the third day). How one understands the gospel has a direct correlation to how one engages the culture missionally. King makes a compelling point when he says, "The gospel at its best deals with the whole man, not only his soul but his body, not his spiritual well-being, but his material well-being" (1986:37-38). It is a message that invites everyone into communities of shalom - beloved community - and one that identifies and likewise confronts individual and social evils that disrupt this shalom.

\subsection{Missions}

Depending upon one's social location or hermeneutical framework, "missions" can take on different meanings. Mark Lau Branson writes, "We read the Bible differently when we are engaging our neighbors. We see things in the text that we had not seen, and the text can shape us to listen and engage our neighbors in different ways" (2014:32). From Branson's statement we can gather that mission is not the imposition of the gospel upon one's neighbors, but it is contextualized by one's neighbors' experiences. The gospel narrative is therefore in conversation with the narrative of those with whom Christians engage. Since the Spirit of God is already active and at work in the world, missions is God-centered, rather than church-centered. According to Kirsteen Kim: 
Mission as God's mission implied a move from the periphery of church and theological concerns - as the activity of enthusiasts in far-away places - to establish mission as an intrinsic part of what it means to be Christian and to be church ... Therefore mission is not an external activity imposed by church leaders on top of all the other demands on church members. Mission is a heartfelt but the spontaneous outworking of the inspiring, transforming, life-giving work of the Holy Spirit.

2012: Loc. 709, Kindle Edition

This raises two important questions: "What is God already doing?" and "Where is God already doing it?"

Just as the gospel narrative cannot be reduced to a single message, mission cannot be understood as a one-dimensional ethic. It must necessarily take on a prophetic character. "The [Gospel and Our Culture Network] GOCN reminds us that western culture, once a Christian epicenter, has become a mission field. [The GOCN] has called the whole church to more fully engage culture in a prophetic and missionary manner." (Ott et al. 2010:440). Hak Joon Lee claims that Martin Luther King, Jr. was a "mission-driven person ...[and] lived an intense mission-oriented life" (2018:208). His analysis of King's "beloved community" concept encapsulates the multidimensionality of missio Dei and serves to further frame missions:

Going beyond a traditional ecclesiocentric view, King's life and ministry offer a wonderful example of the holistic nature of Christian mission. King's view of mission was thoroughly theocentric: Christian mission flows from God and it exists to achieve God's will and desire, which is articulated as the beloved community. In God's mission, God invites humanity to be companions in achieving that goal. I claim that King's idea of the beloved community and his missional life offer a communal moral purpose and a sociopolitical contour to Christian mission. To identify the beloved community as the historical goal of missio Dei has huge implications in understanding Christian mission. It not only makes the communal-political engagement and social witness an integral - not optional - part of Christian mission but also delineates how Christians missiologically approach public issues.

LEE 2018:207

There must be a prophetic consciousness in the church in order to identify the activity of the Spirit moving toward this idea of the beloved community. 
In other words, to participate when God is inviting, but also where God is confronting. This is where Brueggemann's tasks of prophetic ministry can inform missions and frame the use of the camera to achieve missional aims.

\section{Brueggemann's Tasks of Prophetic Ministry}

The term 'prophetic' is commonly understood as communicating about that which will transpire in the future, a kind of "speaking forth." However, building from Walter Brueggemann's definitions here, we find a creative interpretation of 'prophetic' that both reflects the truth of reality while simultaneously providing the impetus to engage in change. This, as we will see, is the basis upon which we can view film as a prophetic tool.

Brueggemann sets out to articulate how the prophetic ministry functions inside of a cultural context that inherently conflicts with Judeo-Christian ideals. The task, he suggests, while introducing an alternative consciousness, produces necessary creative tension as the prophet "[is] naturally in 'subcommunities' that stand in tension with the dominant community" (Brueggemann 2001: Loc. 149, Kindle Edition). Brueggemann uncovers the insidious aspect of the dominant regime that he also identifies as "royal consciousness." He claims that this was the central focus for Moses, the consciousness that undergirded the [royal] regime [of Pharaoh] that tended to be oppressive to its citizens (2001:21, emphasis mine). The prophetic ministry asserts an alternative way of thinking and being that seeks to dismantle the structures of the regime that are rooted in this oppressive consciousness. The dismantling is necessarily a public event or series of events. Both Moses's and King's prophetic, public ministries were not for the purpose of personal or individual reflection (although that may occur) but rather aimed at "the formation of a countercommunity with a counter consciousness" (Brueggemann 2001:21).

In order to evoke this new consciousness, Brueggemann offers two essential qualifiers for prophetic ministry: criticizing and energizing (2001:3). Prophetic ministry criticizes royal consciousness and energizes the oppressed and marginalized "other" who will be edified by the alternative consciousness. This must be a both/and strategy. Both criticizing and energizing are necessary to dismantle and build anew. Royal consciousness is strategically and persistently managed by the state or empire, which has shown resiliency in maintaining status quo. Empire, as it pertains to a US society organized by race, cannot be disentangled from its undergirding ideology of white supremacy, which will instinctively resist the efforts of prophetic ministry. 


\subsection{Criticizing Royal Consciousness}

I wish to argue that modern-day white supremacy may be seen as analogous to the royal consciousness (empire) in Moses's day. I use the terms "royal consciousness," "royal regime" and "white supremacy" interchangeably or together (e.g., "the royal consciousness of white supremacy") throughout this paper when referencing the dominant White community that holds power in the United States. White supremacy, like royal consciousness, insists uncritically that the status quo is beneficial for everyone (Brueggemann 2001:4). The new consciousness, instead, critiques the status quo, energizes those oppressed under such a regime, and offers an alternative way of thinking and being that serves to ultimately dismantle the dominant consciousness (Brueggemann 2001:3). The status quo is dangerous in that it is a space for the normalization of attitudes and deeds that go unchallenged and breed apathy in its citizens. King recognized this danger in the context of White segregationists committed to maintaining the status quo in their context (1986:292). Advocates of the status quo are "unable to be seriously energized to new promises from God" (Brueggemann 2001:3).

On the other hand, an energized royal consciousness will naturally respond with counter resistance, as it "cannot tolerate serious and fundamental criticism" (Brueggemann 2001:4). For many people, dominant social narratives "seem unexceptional and 'true' - demanding no particular improvement or expansion" and certainly not the label 'dangerous'! On the other hand, "[d]ivergent new narratives, ones that could jar and change us, always spark resistance; we reject precisely those narratives that could save us from history's judgment" (Delgado and Stefanic 1991: 1953).

In other words, the royal consciousness that oppressed the Israelites and the white supremacy that has done the same to people of color in modern history both thrive in societies that slumber, content with the 'status quo.' However, the prophetic ministry cannot sleep by nature. In true gospel narrative form, it is proclamation and embodiment of truths and it asks the questions that arouse the collective conscience of the people for the purpose of reorienting them towards the supremacy of a just God.

The prophet(ess) is arguably the missionary to the church and the camera can be considered her sword. The camera serves to disrupt the normalization of anti-Black violence - even as many evangelical pulpits remain silent - as the camera's content is the critique of the royal consciousness that is white supremacy. The content (i.e., filmed reality) reflects the actions of adherents of the royal consciousness right back to them, as well as to the wider public. For example, Derek Chauvin's murder of George Floyd being filmed and broadcast publicly and in courts of law, such that there was no escaping the reality 
of excessive police violence, particularly against Black men. There is no liberation for society without first acknowledging the legitimacy of the camera's content. It is the history of anti-Black violence that white supremacy attempts to escape. "Is it really that bad?" "Is this just an exaggeration?" "Is it just your opinion?" Film unequivocally puts the lie to such attitudes. Thus, normalizing this behavior (or maintaining the status quo) is in the best interest of white supremacy.

However, before it liberates society, the content of the camera serves to haunt the royal consciousness of white supremacy. The concept of haunting has usefully been defined as "the animated state in which a repressed or unresolved social violence is making itself known ... and [its] impacts felt in everyday life, especially when [it is] supposedly over and done with" (Bery 2016:140). ${ }^{2}$ The critique of the royal consciousness of white supremacy must lead to complete deconstruction of all forms of white supremacy and to the construction of an alternative consciousness, as the two cannot coexist. I agree with Brueggemann when he uses the cross as "the ultimate metaphor of prophetic criticism because it means the end of the old consciousness that brings death on everyone" (2001:10o). In other words, it is the finality (or the prospect of finality) of the dominance of the royal consciousness of white supremacy that invites the energy to form a counter consciousness. A narrow gospel message and mission that offers a counter-consciousness frames the work of the cross as exclusively an act of love for humanity. But the cross represents an episode in the broader gospel narrative. The gospel is the story of the finality of the reign of any false, humanly constructed sovereigns (white supremacy) and the reorientation to the true Sovereign One.

\section{5}

\section{White Supremacy and the Royal Narrative}

Generally, white supremacy is understood to mean the superiority in quality of Whiteness in terms of beauty, civility, intellect, and morality as compared to other ethno-racial groups. White supremacy is the product of the joint efforts of Enlightenment era theology, science, education (universities), and the law. According to Jeannine Fletcher Hill, white supremacy was justified theologically by Christian supremacist theology that claimed, "The theo-logic ... rests on the singularity of God's plan for humanity and a sliding scale of humanity that allowed White Christians to argue themselves closer to God's favor and their non-White, non-Christian others deficient in God's eyes" (2017:12).

2 Bery notes that she is drawing from Avery F. Gordon's (2011) definition of haunting. 
Through education systems within the United States, it was expanded by colleges founded by slaveholders where "the theology of Christian supremacy played a pivotal role as bedrock to the white racial frame" (Hill 2017:14). "Race science" reified the notion of white superiority and stratified society along constructed racial lines with white atop the hierarchy. Finally, the law further organized society along white-dominant racial terms by turning ideology into structures and systems (López 2006:79). This "theo-logic" is a type of gospel in and of itself for the dominant group. It is out of this context that the royal narrative of white supremacy is formed.

\subsection{Energizing Alternative Consciousness}

While the camera is effectively used to confront and critique the royal narrative, it is also energizing because it provides the evidence for a counter narrative which invites the creation of a new consciousness that may lead to a counter-community. Not just another divided community, standing in opposition to the royal consciousness, but a new, unified 'beloved community' joined together in opposition to unjust structures which hinder the full flourishing of the gospel. The use of the camera as an extension of Black moral agency meets Brueggemann's energizing criteria for the prophetic. He asserts, "prophetic ministry has to do not primarily with addressing specific public crises but with addressing, in season and out of season, the dominant crisis that is enduring and resilient ..." (2001:3). Systemic racism in the United States has proven to be the dominant, enduring crisis that has plagued the nation for centuries and left no one untouched by its traumatizing effects. It is baked into the fabric of American history, beginning even before the nation's founding (1776), with European colonization of the Americas. ${ }^{3}$ When the content of the camera stands to criticize white supremacy, it has the potential to energize a movement for justice from the margins.

Recent studies show the video of George Floyd's murder has in fact aroused the collective conscience of the dominant group in the United States, if only

3 While there is not space here to discuss the history of the colonization and foundation of the United States, it is important to bear in mind that our examination of contemporary racial issues should be seen within this wider historical context, which includes European colonization of the Americas and the transatlantic slave trade. For example, the earliest enslaved Africans arrived in what is now the US as part of a Spanish colonizing mission in 1526 , while much larger numbers of enslaved Africans were brought from the sugar plantations in Barbados in 1670 during the founding of Charles Town and the Province of Carolina, two early British settlements (Wood 1997:64-65), in addition to the familiar 1619 arrival of enslaved Africans at Jamestown. For a helpful introductory overview to this wider discussion, including useful maps, bibliographies and additional online links, see Wikipedia, "Slavery in the Colonial History of the United States" https://en.wikipedia.org/ wiki/Slavery_in_the_colonial_history_of_the_United_States\#cite_note-24. 
temporarily. ${ }^{4}$ As if the videos documenting the previous killings and beatings of unarmed Black people were not enough, Floyd's death is thought to have a longer lasting shift in White people's awareness and opinions on racism. Nolan McCaskill of Politico wrote, "Public opinion on race relations and police misconduct has shifted dramatically since the killing of George Floyd in Minneapolis, with Americans significantly more likely to say they believe in systemic racism ..." (McCaskill 2020). ${ }^{5}$ Sixty percent of White Americans in 2020 now believe racism is a big problem, compared to twenty-one percent in 2011, according to a CNN/Kaiser Foundation Poll (McCaskill 2020). ${ }^{6}$ These promising statistics were short-lived. By March 2021, according to a USA Today/ Ipsos poll, that sixty percent has dropped to thirty-six percent (Page et al. 2021). This does not mean the camera was ineffective. It does suggest, however, that God's mission, inherently a liberative mission to free the oppressed from interpersonal and structural sin, will face counter-resistance from those in power or close proximity to power.

White supremacy is relentless in its self-preservation. It sustains itself by trafficking in the royal narrative (e.g. Donald Trump's dog whistling and misinformation campaigns) to those who want to hear it. A barrage of criticism filled with misperceptions of Black Lives Matter and Critical Race Theory spread rampantly. While the camera, with its content, energized a countercommunity opposing the royal narrative, it must be noted that the camera and the energy it inspired from the margins provoked the dominant community to its own counter action, be it information warfare, a violent insurrection to stop congressional procedures, ${ }^{7}$ or deceptively changing laws and policies to hinder those participants of social movements.

4 Significantly, Floyd's filmed murder has also elicited transatlantic responses, raising issues of race/racism, colonial history, economic exploitation, and more. Such a global response further speaks to the power of film to convict and call us to action.

5 See https://www.politico.com/news/2020/06/10/george-floyds-death-transforms-views-on -race-307575.

6 When making an even more specific inquiry as to how much of a problem systemic racism is in law enforcement following the killings of unarmed Black people, the same increase is seen. McCaskill continues: "In a Washington Post/Schar School (George Mason University) poll ...69 percent of respondents - including 68 percent of Whites - said Floyd's killing was part of a broader problem within law enforcement. That represents a large increase from a December 2014 ABC News/Washington Post poll, when only 43 percent of all respondents and 35 percent of Whites said then-recent police killings of unarmed Black men were signs of a broader problem" (McCaskill 2020).

7 This is referring to the insurrectionist attack on the US Capitol on January 6th, 2021, as Congress convened a joint session to certify the victory of President Joe Biden in the 2020 election. 
Historically, on the mission field, when missionaries were murdered in foreign lands as they shared the gospel, their deaths served to inspire more missionaries to risk their lives in the same way, taking their places as the next generation of missionaries to a particular people group. ${ }^{8}$ In the same way, African Americans and allies alike must envision themselves being further emboldened by resistance from the royal regime of white supremacy who lack vision or desire for an equitable society or who attempt to "kill" the message and movement for justice.

Jesus is like a modern-day playwright, narrating dramas and creating visuals with his storytelling abilities, helping his audience to understand, embrace, and embody the kingdom. Often times, his parables depict a protagonist and an antagonist. He is often demonstrating what King would describe as "creative tension," with parables that "reflected and expanded the Jewish experiences of his audiences" (Stern 2006:1). His pedagogical brilliance conveyed deep theological truths to the unlearned by inviting them to employ their imagination, while simultaneously confronting the blinding legalism of the Pharisees and Jewish leaders. In other words, "Jesus' words triggered Jewish images in their minds" (Stern 2006:1). What must not be lost is the fact that Jesus preached the gospel of the kingdom of God, and that gospel, core to his parables, exceeded conservative evangelical limits of a salvation message, but boldly criticized social injustices among the Jewish people, much like the prophets of the Old Testament.

For instance, the parable of the Good Samaritan in Luke 10 is an example of Jesus criticizing and energizing his audience. To be clear, this is a kingdom message with penultimate and ultimate implications built into its narrative. Jesus uses this parable to answer the questions about the penultimate (righting a wrong) and the ultimate (eternal life). He criticized the priest's and Levite's actions for perpetuating the injustice and discrimination initiated by the robbers through their avoidance of the assaulted man left for dead. Jesus also invites the lawyer, the rest of the listening audience, and the modern-day

8 It has been argued, for example, that the 1956 murder of five American missionaries (Jim Elliot, Ed McCully, Roger Youderian, Pete Fleming, and Nate Saint) in the context of evangelising the Waorani, an indigenous people group in Ecuador, galvanized an entire generation of missionaries. See, for example: Melani McAllister, The Kingdom of God Has No Boundaries: A Global History of American Evangelicals (Oxford: Oxford University Press, 2018), 22-23. 
reader to locate themselves in the narrative. With whom do we identify? Anonymous victim, religious leader, assailant, lawyer, helpful inn keeper, generous Samaritan? And of course, we are invited to ask, along with the lawyer, "who is my neighbor?" The injustice created the opportunity for these men to participate in the mission of God. In the parable, Jesus describes what it looks like to inherit eternal life (ultimate). He does this by highlighting actions that address the immediacy of the injustice (penultimate).

Ironically, and in a shocking reversal of cultural and religious norms, Jesus used the Samaritan man - 'unclean,' marginalized, and so despised by the Jews - as the image of the ideal neighbor who would inherit eternal life rather than using the Jewish men, as would have been expected and accepted by his listeners, especially the lawyer. Stern asserts, "Jesus used parables to hide information he alone understood and wanted to convey only to his supporters dangerous information that contradicted conventional wisdom and irritated the leaders of the Jewish people. By uncovering the secrets hidden within his parables, we come to understand why some Jews were attracted to his teachings but many Jews were shocked and appalled by them" (2006:1).

Certainly, the Jews hearing his teaching would have been angered by the imagery and insinuation that Samaritans could share in the promises of the kingdom! But Jesus presented a prophetic counter-narrative nonetheless. His parables invite one to engage the imagination through his word-pictures. He understood the value in narrating a drama for his audience in order to reorient them heavenward.

While we may have lost some of the storytelling skills honed in oral cultures, film continues to offer us windows into other realities. With many in our communities, and arguably our nation, unable to imagine anything beyond their own particular realities, the camera is indispensable. Where there is no imagination, there must be an immersion into the spaces of the lived reality of the "other." The content of the camera confronts and criticizes; and while it invites, it energizes. It invites the audience to imagine themselves making a "cameo" in the scene of the drama. Like Jesus' word-pictures, filmed images invite the audience to look and to consider their place in the story, whether becoming like the Samaritan man and coming to the aid of the man left for dead, or the father in the story of the prodigal son. It is an invitation to embody a prophetic witness reflecting the character of God in real time, energizing the viewer/community.

In revealing injustices that have been unseen by the collective eyes of the nation and undiscerned and unfelt by the collective conscience of the nation, film critiques those who participate in the injustice, those who facilitate spaces for injustice to thrive, or those who remain silent in the face of injustice. The 
mission of the church in joining God where God is at work is not only to share the narrative of the good news of Jesus Christ and the "here-but-not-yet" kingdom of God, but also to reveal and confront that which is antithetical to the good news, and consequently, the beloved community. Ironically, it is the very injustice that constitutes the content of the camera that proves the relevance of the gospel message.

The Camera - From the Civil Rights Movement to George Floyd

What has been characteristic of the African American experience since the first enslaved Africans were brought to what would become the United States the lack of access to resources necessary to resist and upend white supremacy. In other words, there has always been proactive and systematic prohibition to Black moral agency nurtured within white power structures, including the US American evangelical church. This reality has forced African Americans to improvise and creatively utilize every available means to fight injustice. The only alternative, as King states, is "submission to injustice," which he calls suicidal (1986:180). The video camera, as a cultural artifact, has been an essential tool for this purpose, particularly since the days of the Civil Rights Movement.

The nation was riveted by the footage of "Bloody Sunday" on March 7, 1965 . African American protesters, including the late John Lewis, were marching "to dramatize for the nation ... and the world" for the right to vote (NBC News 2021). The 1992 beating of Rodney King by police officers in Los Angeles, CA, where the officers were acquitted of all charges, led to the social unrest of the LA riots. The 2014 murder of twelve-year-old Tamir Rice, captured on video, showed officers shoot and kill Rice in Cleveland, $\mathrm{OH}$, within seconds of arriving on the scene. These videos (to name a few) preceded the 2020 filmed murder of George Floyd and did not necessarily culminate in the justice which the community sought. But they reflect a community that has had to creatively improvise and use the resources at hand - in these cases, film - just to stand a chance at justice.

While cameras and video cameras were once specialty items in terms of cost and accessibility, the advancement of technology has democratized the camera. Today, ordinary citizens with a smart phone and social media platform can leverage their own "power" and assert moral agency much in the same way as their Civil Rights Movement predecessors.

The camera is not prophetic or characteristically missiological in and of itself. It is what the camera provides - images, reflections, evidence, impetus that allows it to claim these functions. It is worth mentioning that the irony of 
King's use of the camera as part of his nonviolent strategy is that this very tool, initially used against him and the movement that he co-opted, was what he used to benefit the movement and ultimately as a catalyst for social change. The surveillance technology available to the state - the royal regime - used to manufacture a narrative to discredit King and the movement as a whole was the same technology used by the movement to expose white supremacy and its anti-Black tactics for the world to see (Branch 1988:692).

Though not an exhaustive list, the camera is relevant and effective for three reasons: 1) it is nonviolent and non-threatening, 2) it is creative, 3) and most importantly, it contains fact-bearing content - empirical data. In any fight for justice where the group in power has the resources to dominate those without power, there is the need for a tool that does not explicitly pose an existential threat to them or provoke them to further violence. In the Derek Chauvin murder trial, these characteristics were observed. The "star witness" in the trial, among many compelling witnesses, was the content of then-eighteen-year-old Darnella Frazier's camera phone video as she captured Chauvin's murder of George Floyd. Ironically, the only violence witnessed is already provided by the oppressor. The video camera, though an inconvenience for the royal/dominant regime (e.g. law enforcement) cannot be viewed as an aggressive or violent tool in spite of violent language sometimes used in describing its use (e.g. "point and shoot," or "capture an image"). This is especially effective for King, because he believed that nonviolence disarmed the opponent and did not compound hate and violence, but instead "awakens a sense of shame within the oppressor" (1986:12). Frazier's presence with the camera posed no immediate threat to the officers kneeling on Floyd's neck and back, but it did pose an appropriate long-term threat to the normalized culture of unjust policing in Black communities and contributed to Chauvin's murder conviction.

Furthermore, film has the creative potential to hold power accountable, if not in the moment, certainly to curtail future acts of injustice. It creatively positions the individual or group in power, when in front of the camera, to provide the content. Their actions will either confirm the narrative of the dominant consciousness - that all is well - or refute it, exposing injustice and welcome the possibilities and the urgency of a new narrative (e.g. the aftermath of the release of the George Floyd video). In "Letter From Birmingham City Jail," King articulates the motivation behind the strategy of nonviolent direct action, which incorporated the use of television cameras to document events as they unfolded. He writes, "Actually, we who engage in nonviolent direct action are not the creators of tension. We merely bring to the surface hidden tension that is already alive. We bring it out in the open where it can be seen and dealt with ... injustice must likewise be exposed, with all of the tension its exposing creates; to 
the light of human conscience and the air of national opinion before it can be cured" (1986:295, emphasis mine).

Lastly, it is effective because it contains actual truth-telling content. The content is what allows the camera to function as a type of witness with critical testimony to make the case to convict (Whiteness) or acquit (Blackness) - free "Blackness" from the distorted royal narrative. The content provides the substance for the camera to be the instrument of Black moral agency amplifying the collective Black voice proclaiming back to power the reality of the Black experience and the demand for justice. The content is empirical data for the alternative narrative necessary for a new consciousness or "conversion." It is true that video footage can be taken out of context; it can be misinterpreted, depending on who does the interpreting; or it can prove to be insufficient in achieving justice. However, the "data" (footage) nevertheless forces us to acknowledge, recognize, and interpret what was once ignored by the dominant power structures; in this case, white power structures.

The camera not only publishes conspicuous anti-Black violence, but it also reveals the hiddenness of white supremacist power structures. The power of whiteness, according to Matthew W. Hughey, is that it "stem[s] from its mundane normality" (2016:202). Hughey claims that the invisibility and normality of whiteness is an important insight to note, but argues that there should not be an overemphasis on white racial unconsciousness (2016:202). On the contrary, I contend that because of the implications of its invisibility and the lack of conscious awareness of the racial power structures that have historically translated to intergenerational trauma from countless deaths of African Americans, there cannot be too much emphasis placed here.

This is where the use of the camera is indispensable. At the risk of traumatizing or restimulating pre-existing trauma, film's public revelation of anti-Black violence can potentially shock those who are unaware of the discriminatory and racialized power structures in which they exist into an awareness of the accepted normalcy of a culture of injustice. This awareness then requires viewers to decide whether or not they want to participate in the formation of a more just, counter-community.

\subsection{An Alternative Gaze}

The gaze of white supremacy is perceived and felt by African Americans as a look that ranges from curiosity (who or what "kind" of other is he/she) to condemnation. The camera offers a conversion to an alternative gaze of contemplation. How is the camera used in this way by ordinary citizens, relevant to the prophetic ministry and the mission of the church? This section will attempt to 
engage this question by affirming the camera's relevance for missions through using the framework of Walter Burghardt's theology of contemplation. Simply put, contemplation, is a "long, loving look at "the real" (Burghardt 2008:92). Burghardt goes beyond the common understanding of contemplation as reflection on the abstract or in deep thought or prayer: "The real, reality, is not reducible to some far-off abstract, intangible God-in-the-sky. Reality is living, pulsing people; reality is fire and ice; reality is the sun setting over the Swiss Alps, a gentle doe streaking through the forest; reality is a ruddy glass of Burgundy, Beethoven's Mass in D, a child lapping a chocolate ice cream cone; reality is a striding woman with wind-blown hair; reality is the risen Christ ... what I contemplate is always what is most real" (2008:92). James Lorenz translates Burghardt: "In other words, to be truly contemplative is not a matter of meditating on some abstract notion of a celestial and intangible God, but rather a matter of attending to the tangible flesh of our worldly existence within creation" (2020).

Not all that is contemplated, however, is beautiful or pleasing to the eye, but "includes sin and war, poverty and race illness and death ..." (Burghardt 2008:93). However, that is not gratuitous. One key example of this, of course, is the public crucifixion of Jesus, which gave those present an opportunity to contemplate - to gaze, or take a long, loving look at "the real." God, as the ultimate reality, endures the violence and injustice of sin, which in turn prompted responses from those present. As Mark's gospel records, "And when the [Roman] centurion, who stood there in front of Jesus, saw how he died, he said 'Surely this man was the Son of God!" (Mk 15:39). In the same way, the camera today invites the audience to gaze at the violent reality of the Black experience it displays and to consider how to respond: whether to turn away from this reality, or to respond in lament, compassion, and righteous indignation, and then engage in activism.

The "long, loving look" is described by Lorenz in the context of filmmaking as a "cinematic gaze" (Lorenz 2020). The term 'gaze' has relevance for the African American experience in bringing to the forefront the concept of 'white gaze': "The white gaze is also hegemonic, historically grounded in material relations of white power: it was deemed disrespectful for a Black person to violate the white gaze by looking directly into the eyes of someone White. The white gaze is also ethically solipsistic: within it only whites have the capacity of making valid moral judgments" (Yancy 2013:33). This is where the democratized camera in African American hands is unique and necessary. It reorients the white gaze and forces a deep look at the unjust and tragic reality of anti-Black violence at the hands of White America, whether law enforcement or citizens. 
As noted earlier, there are many tensions surrounding power dynamics and ethics with the use of film. However, in the hands of African American social justice activists, the camera/video camera's function, content, and motivation - whether intentional like King during the Civil Rights Movement or by chance like Darnella Frazier - serves to reorient the public's collective eye to lament, to be active in the work of justice, to foster formation of the beloved community, and to participate in missio Dei.

This is the "alternate gaze" that is offered. An appropriate question to ask is, in the same way that the narratives of Jesus' parables presented an alternative vision of and path towards salvation, can this alternate gaze offer a type of salvation from racial and structural supremacy? The camera, providing this reoriented gaze, invites the royal consciousness to be converted. Conversion, theologically, always requires a change in thinking. Bevans and Schroeder write, "If mission is about a call to conversion - and it is - the conversion has to be understood [as a call] to imagine the world differently" (2011: Loc. 1158, Kindle Edition). Likewise, with the gospel accounts of Jesus' crucifixion, we see this alternate gaze, with the public's shifting gaze moving from curiosity about Jesus (for example, Pilates' question, "are you the king of the Jews?") to condemnation ("crucify him!") to contemplation (for example, women watching from a distance; the centurion's declaration that "Surely this was the Son of God!"). In offering an alternate gaze, the camera's content offers the possibility of moving us from curiosity or condemnation of the 'other' to empathetic contemplation, with the invitation to join in the wider missional work of justice.

\subsection{The Camera Phone}

In a recent interview on NBC's Dateline, George Floyd's brother Philonise Floyd spoke to the fact that while many families have experienced the same pain of losing a family member to police violence, not all of their deaths elicited the same responses as Floyd's murder. Philonise said, "Nobody cared because they didn't have the footage." The families shared their stories with him while expressing disappointment that there was not much concern for their tragedies. Acts of anti-Black violence that are reported without video do not sufficiently dramatize the event. The performance of white supremacy must be witnessed. The dramatization of the event is what invites or entices one to "gaze," much like a teaser or trailer convinces the potential audience to come back to witness the entire narrative. Art shares the characteristics of nonviolent direct action as described by King: "Nonviolent direct action seeks to create such a crisis and establish such creative tension that a community that has constantly refused to negotiate is forced to confront the issue. It seeks to 
dramatize the issue that it can no longer be ignored" (1986:291). Camera phones are not designed to tell the whole gospel narrative, but can capture injustice in order to refute the dominance of the royal narrative of white supremacy that typically conceals anti-Black violence. The democratization of the camera phone also means that the truth of these events and realities are no longer under the control of the state/empire/power structures.

What makes the camera phone such an effective tool for ordinary citizens within the context of highlighting racial injustice (at least within the US) is that it has been democratized. King was at the mercy of the media personnel and networks to not only document these events, but to actually air them in their proper context and to broadcast the facts honestly. That monopoly of power has been subverted by technology - smart phones, internet, social media - and so has the monopoly on the narrative around social injustice. This is as necessary to the gospel mission of justice as the democratization of the Holy Spirit at Pentecost increasing the breadth of the gospel's reach and the efficiency of its movement to counter the royal narrative that traffics in the sin and violence of injustice.

\section{8}

\section{Conclusion}

The gospel story is an ongoing narrative. The most important event in the narrative is the crucifixion, death, burial, and resurrection of Jesus. However, what is also "good news" is that the Spirit of God has been democratized as the Spirit indwells all believers, empowering them to continue the work of Jesus as the church. The mission of the church, joining God's activity in the world, must be an embodied mission confronting that which perverts what God originally intended to be good in the world. The gospel, more than an event, is in its essence God's plan to right the wrongs brought upon creation by the reality of sin. Justice is the righting of wrongs.

Jesus used parables to paint word-pictures to confront, challenge, and inspire his listeners. Sometimes this meant reflecting their own brokenness back to them, and at other times, helping them to imagine greater possibilities for human flourishing and wholeness. As this article has argued, within the context of American racial justice movements, film has functioned in a similar way. From the Civil Rights Movement to camera phones capturing George Floyd's murder, social justice movements could not have achieved all that they have over the last sixty-five years without the camera. However, there is still far to go. 
The camera has become a necessary prophetic and catalytic tool with a dual purpose, particularly for African American Christians. This includes firstly confronting structural racial injustice by exposing it; and secondly, inviting viewers into the new narrative, or gospel, of justice and salvation proclaimed and embodied by Jesus Christ. This new narrative should not be understood as simply a counter-community to an existing culture of perpetuated injustice and inequities - which can simply become a different version of 'us versus them' - but a new, unified community that is an intentional witness to shalom; the beloved community.

Questions of justice and human flourishing involve all of us, and have global implications. Those present at Jesus' crucifixion and death included his Jewish followers as well as Gentiles; peasants and those from the ruling elite; men and women, old and young. Some who witnessed the event simply turned away. Some, like Pilate, were momentarily troubled but ultimately chose to uphold the status quo. But for others in that moment, a new and beloved community was born. As we are reminded in Ephesians, "For he himself is our peace, who has made the two groups one and has destroyed the barrier, the dividing wall of hostility. [...] His purpose was to create in himself one new humanity out of the two, thus making peace, and in one body to reconcile both of them to God through the cross, by which he put to death their hostility" (Eph 2:14-16). As we consider the global need for the good news of Christ's justice and peace, the prophetic use of film provides us with a helpful tool to achieve this missiological end.

\section{References Cited}

Bantu, Vince (2020). "An Introduction to Gospel Haymanot." In Vince L. Bantu, ed., Gospel Haymanot: A Constructive Theology and Critical Reflection on African and Diasporic Christianity. Chicago, IL: Urban Ministries, Inc.: 9, Kindle Edition.

Bery, Sadhana (2016). "Making Whiteness in Reenactments of Slavery." In Stephen Middleton, David R. Roediger, and Donald M. Shaffer, eds., The Construction of Whiteness. Jackson, MS: University Press of Mississippi: 140-170, Kindle Edition.

Bevans, Stephen B. and Roger P. Schroeder (2011). Prophetic Dialogue: Reflection on Christian Mission Today. Maryknoll, NY: Orbis Books. Kindle Edition.

Branch, Taylor (1988). Parting the Waters: America in the King Years 1954-63. New York: Simon and Schuster. Kindle Edition.

Branson, Mark Lau and Nicholas Warnes (2014). Starting Missional Churches: Life with God in the Neighborhood. Downers Grove, IL: InterVarsity Press. 
Brueggemann, Walter (2001). The Prophetic Imagination. Minneapolis, MN: Fortress Press. Kindle Edition.

Burghardt, Walter (1989, 2008). "Contemplation: A Long Loving Look at the Real". In George W. Traub, ed. An Ignatian Spirituality Reader. Chicago, IL: Loyola Press: 89-98.

Delgado, Richard and Jean Stefancic (1991). "Norms and Narratives: Can Judges Avoid Serious Moral Error?” Texas Law Review 69, 1929-1983. Available at: https:// scholarship.law.ua.edu/fac_articles/557.

Gordon, Avery F. (2011). "Some Thoughts on Haunting and Futurity," Borderlands 10, November 2.

Harper, Lisa Sharon (2016). The Very Good Gospel: How Everything Wrong Can Be Made Right. New York: Waterbrook. Kindle Edition.

Haseman, Janie, Karina Zaiets, Mitchell Thorson et al. (2020). "Tracking Protests Across the US in the Wake of George Floyd's Death," USA Today, June 18. https:// www.usatoday.com/in-depth/graphics/2020/o6/o3/map-protests-wake-george -loyds-death/5310149002/, accessed on November 22, 2020.

Hill Fletcher, Jeannine (2017). The Sin of White Supremacy: Christianity, Racism, and Religious Diversity in America. Maryknoll, NY: Orbis Books. Kindle Edition.

Hughey, Matthew W. (2016). "Hegemonic Whiteness: From Structure and Agency to Identity Allegiance." In Stephen Middleton, David R. Roediger, and Donald M. Shaffer, eds., The Construction of Whiteness: An Interdisciplinary Analysis of Race Formation and the Meaning of a White Identity. Jackson, MS: University Press of Mississippi: 202-223. Kindle Edition.

Jennings, Willie James (2010). The Christian Imagination: Theology and the Origins of Race. New Haven, CT: Yale University Press.

Kim, Kirsteen (2012). Joining in With the Spirit: Connecting the Local Church and World Mission. London, UK: SCM Press. Kindle Edition.

King, Martin Luther, Jr. (1986). "Letter From Birmingham City Jail." In James M. Washington, ed., A Testament of Hope: Essential Writings and Speeches of Martin Luther King, Jr. New York: Harper One: 289-302.

King, Martin Luther, Jr. (1986). "Negroes Are Not Moving Too Fast.” In James M. Washington, ed., A Testament of Hope: Essential Writings and Speeches of Martin Luther King Jr. New York: Harper One: 176-181.

King, Martin Luther, Jr. (1986). “Pilgrimage to Nonviolence." In James M. Washington, ed., A Testament of Hope: Essential Writings and Speeches of Martin Luther King, Jr. New York: Harper One: 35-40.

King, Martin Luther, Jr. (1986) "The Power of Nonviolence." In James M. Washington, ed., A Testament of Hope: Essential Writings and Speeches of Martin Luther King, Jr. New York: Harper One: 12-15. 
Lee, Hak Joon (2018). "Community, Mission, and Race: A Missiological Meaning of Martin Luther King, Jr's Beloved Community for Relationships and Identity Politics." In Love L. Sechrest, Johnny Ramirez-Johnson, and Amos Yong, eds., Can White People Be Saved? Triangulating Race, Theology, and Mission. Downers Grove, IL: IVP Academic: $206-228$.

López, Ian Haney (2006). White By Law: The Legal Construction of Race. New York: New York University Press. Kindle Edition.

Lorenz, James (2020). "The Cinema Gaze as 'A Long Loving Look at the Real': Andrei Tarkovsky and Walter Burghardt's Theology of Contemplation." The Heythrop Journal, May 19, 2020: 1-13. https://doi-org.vu-nl.idm.oclc.org/10.1111/heyj.13576.

Madrigal, Alexis C. (2018). "When the Revolution Was Televised." The Atlantic, April 1, https://www.theatlantic.com/technology/archive/2018/o4/televisions-civilrights --revolution/554639/, accessed on October 21, 2020.

McAllister, Melani (2018). The Kingdom of God Has No Boundaries: A Global History of American Evangelicals. Oxford: Oxford University Press.

McCaskill, Nolan D. (2020). “A Seismic Quake’: Floyd Killing Transforms Views on Race." Politico, June 10. https://www.politico.com/news/2020/o6/10/george-floyds -death-transforms-views-on-race-307575, accessed on November 22, 2020.

NBC News (2018). "Bloody Sunday: A Flashback of the Landmark Selma to Montgomery Marches.” March 21. https://www.nbcnews.com/video/bloody-sunday-a-flashback -of-the-landmark-selma-to-montgomery-marches-1191243331868, accessed on June 18, 2021.

Page, Susan, Sarah Elbeshbashi, and Mabinty Quarshie (2021). "Exclusive: Sharp Divide on Race, Policing Emerges Since George Floyd's Death, USA TODAY/Ipsos Poll Shows." USA Today, March 5, 2021. https://www.usatoday.com/story/news/ politics/2021/o3/o5/americans-trust-Black-lives-matter-declines-usa-today-ipsos -poll/6903470002/, accessed on June 18, 2021.

Stern, Frank (2006). A Rabbi Looks at Jesus' Parables. New York: Rowman and Littlefield. Kindle Edition.

Wood, Betty (1997). The Origins of American Slavery: Freedom and Bondage in the English Colonies. New York: Hill and Wang.

Yancy, George (2020). "Walking While Black in the White Gaze." NY Times, September 1, 2013. https://opinionator.blogs.nytimes.com/2013/o9/o1/walking -while-Black-in-the-White-gaze/, accessed on November 10, 2020. 


\section{Resumen}

Mediante los avances tecnológicos y su democratización, se descubre que la cámara cumple una doble funcionalidad. Es una herramienta profética y misiológica que se utiliza para despertar la conciencia colectiva de una nación desinteresada por la realidad negra y también para ofrecer una contra-narrativa que reoriente a los Estados Unidos a convertirse en una sociedad más racialmente justa. Este trabajo considera unas definiciones de evangelio, misiones y lo profético, y define un marco de cómo la cámara funciona para cada una de las tres. Brevemente investiga el uso de la cámara desde Martin Luther King, Jr. durante el movimiento por los derechos civiles, hasta la cámara del teléfono celular de un ciudadano contemporáneo todos captando la violencia contra los negros. Como veremos, lo que las parábolas de Jesús fueron para su mensaje del reino, el contenido de la cámara, al exponer las realidades de la injusticia racial, ha sido vital para lograr confrontar el status quo y revitalizar a los testigos para tomar medidas positivas.

\section{摘要}

通过技术进步和普及化, 摄像机具有双重功能。它既是一种先知性工具, 也是一种 宣教工具, 用来唤醒一个对黑人经历漠不关心的国家的集体良知, 并提供一种反叙 述, 使美国重新定位为一个更加有种族公义的社会。本文考虑了福音、使命和先知 性的定义, 概述了摄像机在这三者中如何运作的框架。它简要地探讨了从在民权运 动期间小马丁路德 - 金到当代公民使用相机电话, 所有这些镜头都捕捉到了反黑人 暴力。正如我们将看到的, 就像耶稣用比喻传扬他国度的信息一样, 摄像机拍摄的 内容已经证明, 通过揭露种族不公正的现实、面对现状和激励观众采取积极行动来 获得公义至关重要。 